\title{
A Review of the Philippine Policies on Mental Health of Overseas Filipino Workers (OFWs)
}

\author{
Ma-Ann M. Zarsuelo ${ }^{1,2}$ \\ ${ }^{1}$ University of the Philippines Manila Health Policy Development Hub \\ ${ }^{2}$ Institute of Health Policy and Development Studies, National Institutes of Health, University of the Philippines Manila
}

\begin{abstract}
The Philippines has been lauded for its labor-export programs and is deemed as a global model of migration by other countries. With the economic and employment challenges in the country, seeking work opportunities overseas becomes a promising option. Numerous policies bring forth to the creation of government agencies that focus on labor protection and welfare promotion of migrant workers here and in their host countries, which include advancement of mental health. This paper aims to review and identify the gaps of regulatory policies that intersect the phases of migration: pre-deployment, deployment, and reintegration. Statistics and anecdotal data show that cases of distressed overseas Filipino workers (OFWs) are increasing given the presence of adverse working conditions across the continents. This problem is compounded by cultural stigma and financial inaccessibility of seeking mental health services. Post-repatriation issues, particularly the concerns on socio-economic reintegration is further noted. Thus, the management of mental health among OFWs calls for a comprehensive review of our existing policies and the delineation of the interrelated responsibilities of all relevant stakeholders for effective multisectoral program implementation. Synchronized endeavors of different agencies for efficient handling of psychosocial programs for OFWs in all stages of deployment is needed. Realistic and sustainable programs to address mental health issues are attainable through collaborative actions, with the foresight of focusing on prevention rather than treatment.
\end{abstract}

Key Words: migrant workers, mental health, labor policies

\section{INTRODUCTION}

The economic challenges in the Philippines continuously push the poor and vulnerable segments of our society to seek employment abroad. In the Philippine Overseas Employment Administration (POEA) report based on 2015 data, there were 2,343,692 overseas Filipino workers (OFWs) where majority were land based (78\%), re-hires (74\%), and females (54\%). Among the 26\% new hires, household service workers (HSWs) continued to be the largest occupational category (38\%), followed by manufacturing labor (8\%), nursing professionals (4\%), and waiters $(3.6 \%)$, respectively. In the span of four years, there was already a $5 \%$ increase in HSW employment among new hires. ${ }^{1}$

To establish the state of mental health of OFWs, a search on studies with key words "mental health" and "Filipino workers" through Google Scholar and on published case reports from various Philippine based migrant organizations was done to pool data on the current evidences.

To date, there are limited published literature on Institute of Health Policy and Development Studies National Institutes of Health University of the Philippines Manila 623 Pedro Gil Street, Ermita, Manila 1000, Philippines Telefax: +6323543832

E-mail:mmzarsuelo@up.edu.ph living conditions and welfare of HSWs but anecdotal data shows that abuse is widespread among Middle East countries, calling for serious government actions. Labor codes of these countries exclude HSWs, hence, falling 
Table 1. Selected migrant labor policies in the Philippines

An Act to institute the policies of overseas employment and establish a higher standard of protection and promotion of the welfare of migrant workers, their families and overseas Filipinos in distress, and for other purposes.

\begin{tabular}{lll}
\hline RA 10022 & $\begin{array}{l}\text { An Act amending Republic Act No. 8042, otherwise known } \\
\text { as Migrant Workers and Overseas Filipinos Act of 1995, as } \\
\text { amended, further improving the standard of protection and } \\
\text { promotion of the welfare of migrant workers, their families } \\
\text { and overseas Filipinos in distress, and for other purposes. }\end{array}$ & $\begin{array}{l}\text { Amendments include guaranteeing migrant workers' rights, } \\
\text { stricter rules and penalties to unregulated recruitment, } \\
\text { selective deployments, and shared government migration } \\
\text { information system, among others. }\end{array}$ \\
\hline RA 10801 & $\begin{array}{l}\text { An Act governing the operations and administration of the } \\
\text { Overseas Workers Welfare Administration }\end{array}$ & $\begin{array}{l}\text { It states the responsibilities of the government on the full } \\
\text { protection to labor of overseas Filipino workers (OFWs). }\end{array}$ \\
\hline RA 9710 & Magna Carta for women & $\begin{array}{l}\text { It promotes empowerment of women and pursues equal } \\
\text { opportunities for women and men and ensures equal access } \\
\text { to resources and to development results and outcome. }\end{array}$ \\
\hline AO No. 168 & $\begin{array}{l}\text { Manual of operations, policies, and guidelines for the } \\
\text { Philippine Overseas Labor Office }\end{array}$ & $\begin{array}{l}\text { It states that POLO is Department of Labor and } \\
\text { Employment's (DOLE) overseas operating arm in the } \\
\text { implementation of Philippine labor policies and programs } \\
\text { for the protection and welfare of OFWs. }\end{array}$ \\
& &
\end{tabular}

short on welfare and protection policies. In addition, several domestic workers fall prey to illegal recruitment of unregulated private agencies that manipulate the contract and application process. These scenarios expose them to high risk of abuse such as overwork, under- or non-payment of salary, withholding of passport,inaccessible communication, trafficking, and physical and sexual abuse. Should such abuse occur,circumstances are further aggravated sinceliving in the employers' residence restricts them to seek help. ${ }^{2}$

The Philippine government endeavors to focus and expand the policies in labor migration system towards the protection and welfare promotion of migrant workers including psychosocial distress. For the purpose of the review, the following labor policies in which provisions include mental health management of overseas Filipinos were hereinafter included.
Despite the protection mechanisms enacted by the government, rampant violations on OFW rights continue to take toll on their psychosocial status. Thus, identifying the gaps in labor policy development and implementation is necessary to achieve the policy target outcomes.

Figure 1 lays out the framework of migratory process of overseas workers. It emphasizes the common psychological stressors in each stage that could lead to distress, andfurther aggravate the risk for mental health illnesses. Timely intervention opportunities span throughout the process where efficient and systematic program planning can arrest potential stressors toprovide appropriate assistance at any point of migration. Regulatory policies involve multisectoral implementation and monitoring to yield synchronized efforts towards securing the protection and welfare promotion of migrant workers.

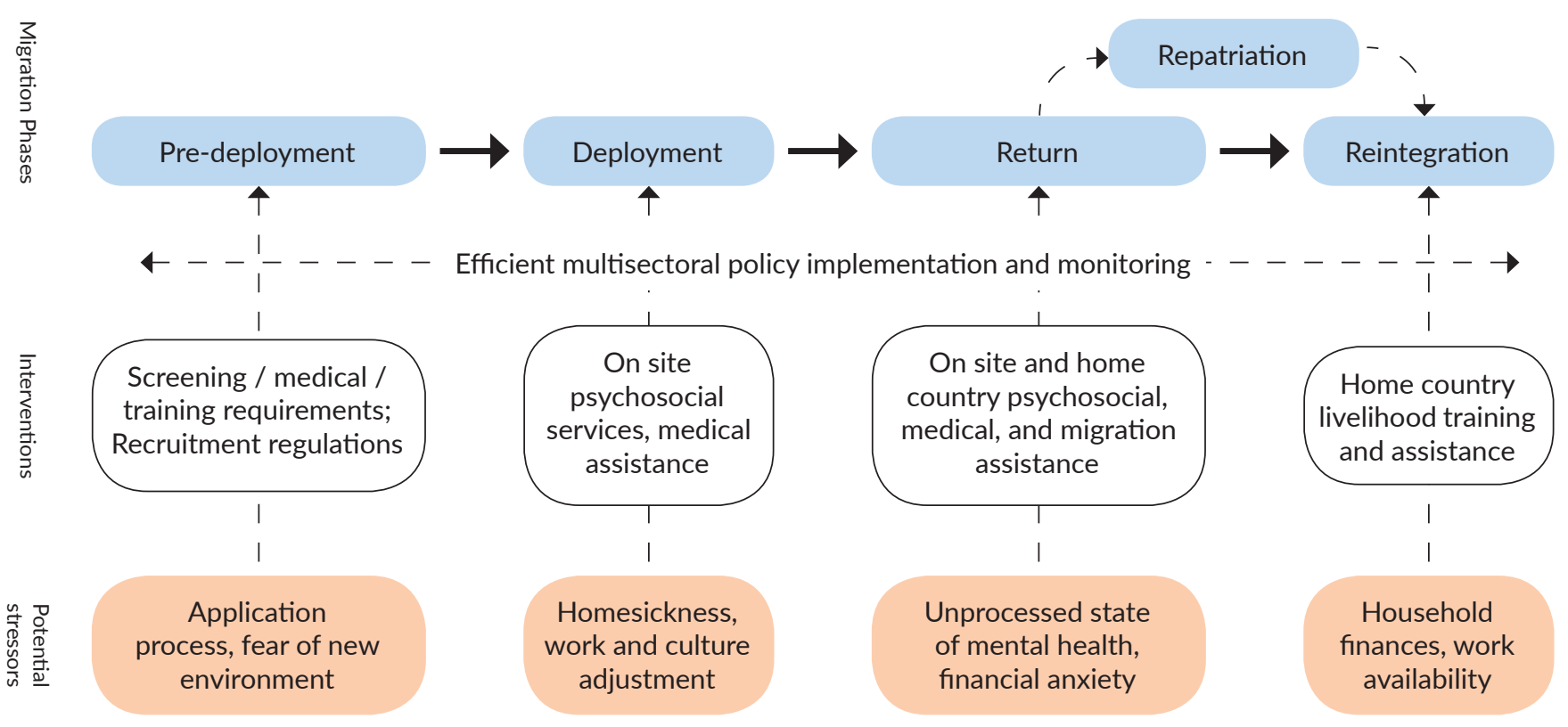

Figure 1. Conceptual framework on the migration process of distressed migrant workers. 


\section{PSYCHOSOCIAL DISTRESS OF OFWS}

Though there is limited literature on psychosocial distress of Filipino migrant workers, all published studies concluded that there is a significant mental health problem regardless of the host country. In the United States, job dissatisfaction among Filipino migrants is directly associated with lower psychological and physical health which are more common among the unmarried and newly employed. ${ }^{3} \mathrm{~A}$ study of caregivers in Canada with 83\% Filipino participants shows that there is unrecognized mental health needs that emerged from stress related work demands. Myriads of overlapping work and the downward social mobility as "captive laborers" compromised their mental health. ${ }^{4}$ This is further supported by the study in Israel where home/work environment among Filipino caregivers is directly associated with high levels of depressive symptoms. ${ }^{5}$ Nevertheless, seeking mental health services was their last priority either due to cultural stigma in the Philippines or lack of awareness on the available services. ${ }^{4}$ In the Philippines, people suffering from psychological difficulties are constrained to seek mental health services due to public discriminatory response (public stigma). Once this is internalized (private stigma), its effects become detrimental as it leads to diminishing selfworth, self-esteem, self-efficacy and eventually, shame in seeking treatment. ${ }^{6}$

On another note, lack of host country policies on protection against discriminatory treatment on social status and gender makes mental health services inaccessible for HSWs. Moreover, the kafala or employer sponsorship system among the Gulf Cooperation Council (GCC) countries leaves HSWs highly dependent on employer in terms of employment, residence visa, and subsequently immigration status. This traps them into abusive situations since fleeing workers might be charged with absconding and therefore fined, imprisoned for six months, deported, and barred from returning for six years. Countries with increased HSW deployment such as United Arab Emirates, Qatar, Kuwait, Malaysia, and Singapore also have the highest unresolved welfare cases. ${ }^{7}$

Stress levels of Filipino domestic helpers are significantly higher among those working abroad wherein primary struggles are related to loneliness and working conditions compared to local domestic workers whose stress are financially related. ${ }^{8}$ In the focus group discussions (FGDs) conducted by the Center of Migrant Advocacy (CMA), HSWs expressed that mental preparation should be a necessary requirement before deployment. Adequate preparation for isolation and homesickness should be provided given the possible adverse working and living conditions, in which participants reported encountering "psychological instability." Reported cases included forbidding to see the contract, restricted communication with family, working 20 to 22 hours a day, and no compensation. ${ }^{2}$ An earlier study on ASEAN migrants in
Malaysia showed that Filipino and Indonesian domestic helpers are vulnerable to develop psychiatric disorders due to harsh working and living conditions. ${ }^{9}$

In February 2018, eleven newly hired domestic helpers from Jeddah, Saudi Arabia were brought to the embassy due to severe mental health problems. The Philippine Consulate in Jeddah called for urgent need of government assistance given the inadequate facilities and trained health professionals to manage the case. Recruitment agencies were also urged to have stricter compliance to screening process wherein medical examination includes neuropsychiatric test. ${ }^{10}$

In spite of the abuse, some HSWs chose to work at the expense of their welfare due to fear of chronic poverty, lack of local economic opportunities, and cultural and psychological pressure of family responsibilities. ${ }^{4,11}$

\section{POLICIES AND REGULATIONS ON MIGRANT WORKERS}

Republic Act (RA) 10022 states that the POEA, in consultation with Department of Foreign Affairs (DFA) will be the sole governing body to issue permit or ban deployment. Deployment of OFWs are allowed only in receiving countries that have the following: (1) existing labor laws protecting rights of migrant workers; (2) signatory to and/or ratifier of multilateral conventions, declarations or resolutions pertinent to protection of workers; and (3) has concluded to bilateral agreement with the government on the protection of OFWs. As such, DFA shall issue certification to POEA on the pertinent provisions of receiving country's labor/social law, convention/declaration/resolution, or bilateral agreement/ arrangement which protect the rights of migrant workers. ${ }^{12}$

In 2006, the need to reinforce policy reforms was heightened after the Lebanon war which placed our domestic workers at risk. Towards the end of the same year, policy reforms on HSWs include the following: (1) no placement fees; (2) minimum age of 23; (3) entry-level salary of USD 400; (4) mandatory culture and language exchange at OWWA; and (4) skills assessment and competency certification (NC II) by Technical Education and Skills Development Authority (TESDA). Furthermore, the Philippines ratified the International Labor Organization C189 in 2012, known as the convention on decent work for domestic workers. It recognizes workers' right to informed terms of employment, fair and effective access to justice, and complaint mechanism for domestic workers. ${ }^{2}$

Protection of HSWs was further strengthened in 2013 when the Philippines and the Kingdom of Saudi Arabia (KSA) signed a bilateral agreement for standard employment contract and benefit packages to guarantee better worker protection of domestic workers. ${ }^{2}$ Despite the passage of this law, the Philippine government issued a deployment ban to Kuwait in February 2018 in response to the reported seven OFW deaths accounted to their employers. This triggered the Kuwaiti government to stress their support in 
signing the long-proposed Memorandum of Agreement on additional protection of Filipino workers. ${ }^{13}$

\section{Pre-deployment}

All aspiring migrant workers shall comply with PreEmployment Orientation Seminar (PEOS), Pre-departure Orientation Seminar (PDOS), Comprehensive PreDeparture Orientation Program (CPDEP), and NCII skills and training assessment. Despite the seemingly comprehensive training package, case reports revealed otherwise. According to the Center of Migrant Advocacy, the aforementioned programs were deemed inefficient in terms of content, quality, approach, and trainers' requirements. ${ }^{2}$

As for the recuriment agencies, penalties for illegal recruitment under RA 10022 includes 6 to 12 years of prison and fine of Php 500,000 to Php 1,000,000. For underage migrants, additional provisions for the agency include revocation of license and refund of all processing and deployment fees to the underage migrant or his/her parents. ${ }^{12}$ Case reports of underage domestic workers showed that agencies themselves assisted in falsifying documents. ${ }^{14}$

\section{Deployment}

Global figures of OFWs with legal cases have been increasingly alarming, with 5,168 in jail for various offenses, including 673 women detainees and 50 minors. ${ }^{15}$ Though the figures decreased in the following years, the 3,732 Filipinos in jail across 53 countries is still an appalling number enough to stir urgency in examining policy gaps. ${ }^{16}$

Pursuant to RA 10022, Administrative Order (AO) No. 168 hereby tasked the Philippine Overseas Labor Office (POLO) as the overseas operating arm of DOLE in implementing Philippine labor policies and programs for the protection of rights and welfare promotion of Filipino migrant workers. Further, Migrant Workers and Other Overseas Filipino Resource Center (MWOFRC) shall be established in countries with high volume of migrant workers under the premises and jurisdiction of Philippine Embassy or Consulate. Services rendered include counselling and legal services, gender-sensitive interventions, medical assistance (physical and mental), temporary shelter for the distressed, and repatriation. The liability for all repatriation and attendant costs will be under the principal or local agency. ${ }^{17}$

Similarly, RA 1081 gives the same responsibilities to OWWA, in which they shall send representatives to employers, agents, and host governments to assist OFWs in obtaining relief from work-related grievances. ${ }^{18}$ These laws are consistent with the RA 9710 (Magna Carta), that the State shall ensure protection and promotion of rights of migrant women in host countries regardless of work status, and protect them against discrimination in wages, conditions of work, and employment opportunities. ${ }^{19} \mathrm{To}$ date, there are 34 POLO offices wherein 11 are situated in Asia, 13 in Middle East, 7 in Europe, and 3 in America; while there are 37 OWWA offices overseas. ${ }^{20}$

\section{Post-repatriation}

For in-country services, OWWA program includes accorded airfare and airport assistance, temporary shelter, transportation allowance to provinces, stress debriefing/ counselling, and referral (psychiatric treatment), regardless of OWWA membership. ${ }^{21}$ In May 2018, Memorandum Circular No. 2018-62, otherwise known Local Government Unit's Roles and Responsibilities in the Implementation of Inter-agency Medical Repatriation Assistance for Overseas Filipinos was released. It aims to harmonize policies, processes, and procedures of relevant government agencies and delineate their respective roles and responsibilities with standard reporting and monitoring system. ${ }^{22}$

Once the migrant workers are reintegrated to the community, socio-economic burden becomes inevitable, particularly for those repatriated with unpaid salaries. The foresight of household financial instability and uncertain domestic employment often leads to anxiety.

Pursuant to Republic Act 10022, DOLE, POEA, and OWWA are mandated to establish the National Reintegration Center for OFWs (NRCO) which develops and implements support programs for livelihood, entrepreneurship, savings, investments, and financial literacy for returning OFWs and their families. Furthermore, TESDA shall give priorities to returnees who had been domestic helpers and entertainers. This is consistent with Section 23 of RA 9710 which states the right to livelihood, credit, and technology of returning women migrant workers. ${ }^{18}$

\section{MENTAL HEALTH POLICIES IN THE PHILIPPINES}

Before Senate Bill 1354 has been ratified to RA 11036, known as Philippine Mental Health Act, mental health legislation and laws are included in various promulgated laws such as Penal Code, Magna Carta for Disabled Persons, Dangerous Drug Act, etc. In 2001, the Department of Health (DOH) released Administrative Order No. 8 series 2001, otherwise known as National Mental Health Policy. ${ }^{23}$ Therein, the National Mental Health Program was created to protect the rights of person with mental illness and to promote mental health. In pursuant to the policy, AO 20070009, otherwise known as Operational Framework for the Sustainable Establishment of a Mental Health Program was implemented with the aim of providing general guidelines for government and private sectors in developing and implementing related programs. It is notable that OFWs are one of the highlighted groups in mental disorder prevention, treatment, and community reintegration. ${ }^{24}$

The endeavor to legislate a mental health law continued until RA 11036 was signed in June 20, 2018. It mandates the government to provide timely, affordable, accessible, and culturally appropriate mental health care services to Filipinos. ${ }^{25}$ Section 3 states that the law aims to strengthen effective leadership for mental health; develop and establish 
responsive national mental health care system; protect the rights and freedom of persons with psychiatric, neurologic, and psychosocial health needs; strengthen information system and research; and integrate strategies promoting mental health in educational institutions, workplace, and communities. The $\mathrm{DOH}$ is tasked as the main government agency to formulate, develop, and implement the national mental health program. ${ }^{25}$ In response to this, several lawmakers reiterated the necessity of sufficient funding to give life to and sustain the programs of the law as the government's commitment. ${ }^{26}$

It is emphasized that RA 7277, as amended, otherwise known as the "Magna Carta for Disabled Persons" is applicable to persons with mental health conditions. Nevertheless, it is striking to note that mental health promotion and protection of migrant workers was not specifically mentioned in the scope of its concerns. However, it is noteworthy that the provision to integrate mental health into the educational system and workplace can raise public awareness on mental health issues and correct stigma and discrimination. ${ }^{25}$

\section{SUMMARY AND RECOMMENDATIONS}

This paper aimed to uncover gaps in the implementation of current policies and provide basis for strategies in addressing mental health problems of OFWs. From the current review, given the policies in place and the rising case reports of abuse, there is a need for a comprehensive analysis on how Filipino migrant workers are protected by our laws. The success of the policies is strongly hinged on implementation, on whether the set rules and regulations are strictly complied with. To arrest the increase in mental health problems of OFWs, there is a need to ensure that migration programs before, during, and after deployment are synchronized and systematic.

To arrive at evidence-based unbiased policy recommendations, all stakeholders of the policy issue must convene to find order in light of the cacophonous reports and arguments on mental health status of OFWs. There is a need for concrete data and comprehensive reporting system concerning different forms of abuse and distress. Similarly, adequate provision of competent human capital in handling the protection and welfare of Filipino migrants in each host country will yield a sturdy backbone on effective policy implementation. Financial and geographical accessibility to mental health services must be secured in host countries and home country regional offices. It is imperative to have a clear navigation of referral system from the host country up to the monitoring of reintegration outcomes of the migrant workers. With the ratification of Mental Health Act, the duties and responsibilities of government agencies as reflected in the future Implementing Rules and Regulations (IRR) can ensure the alignment of policy actions to achieve the objectives of the Act.

\section{Statement of Authorship}

The author approved the final version submitted.

\section{Author Disclosure}

The author declared no conflicts of interest.

\section{Funding Source}

No external funding.

\section{REFERENCES}

1. Philippine Overseas Employment Administration Overseas Employment Statistics Deployed Overseas Filipino Workers 20142015 [Online]. 2015 [cited 2018 March 15]. Available from www.poea. gov.ph/ofwstat/compendium/2015.pdf.

2. Center of Migrant Advocacy. An Assessment of the Policy Reforms for Household Service Workers (HSWs) in the Philippines. 2015.

3. Castro, AB, Gee GC, Takeuchi D. Relationship between job dissatisfaction and physical and psychological health among Filipino immigrants. AAOHN J. 2008;56(1):33-40.

4. Mandana V, Wong JP. Caught between a rock and a hard place: mental health of migrant live-in caregivers in Canada. BMC Public Health. 2017;17:498

5. Ayalon L. Suicidal and depressive symptoms in Filipino home care workers in Israel. Journal of Cross-Cultural Gerontology. 2012; 27:51-63.

6. Tuliao A. Mental health help seeking among Filipinos: A review of the literature. Asia Pacific Journal of Counselling and Psychotherapy. 2014; $5(2): 1-14$.

7. International Labor Organization. Policy Brief No. 2: Reform of the kafala (sponsorship) system [Online]. 2017 July 3 [cited 2018 May 15]. Available from http://www.ilo.org/dyn/migpractice/docs/132/ PB2.pdf.

8. Van der Ham AJ, Batangan MT, Ignaci R, Wolffers I. The Dynamics of migration-related stress and coping of female domestic workers from the Philippines: An exploratory study. Community Mental Health Journal. 2015;51:14-20.

9. Krahl W, Hashim A. Psychiatric disorders in ASEAN-migrants in Malaysia-a university hospital experience. Medical Journal of Malaysia.1998;53 (3): 232-238.

10. GMA News Online. 11 OFWs with mental health problem brought to Bahay Kalinga in Jeddah [Online]. 2018 February 5 [cited 2018 May 12]. Available from http://www.gmanetwork.com/news/pinoyabroad/ news/642234/11-ofws-with-mental-health-problem-brought-tobahay-kalinga-in-riyadh/story/.

11. Sayres, N. Analysis of the situation of Filipino domestic workers. International Labour Organization. ILO Special Action Programme to Combat Forced Labour: Mobilizing Action for the Protection of Domestic Workers from Forced Labour and Trafficking in Southeast Asia. 2007.(Working paper).

12. Republic Act 10022. An Act amending Republic Act No. 8042, otherwise known as Migrant Workers and Overseas Filipinos Act of 1995, as amended, further improving the standard of protection and promotion of the welfare of migrant worker, their families and overseas Filipino in distress, and for other purpose, RA 10022. 14th Congress, 3rd Session. 2009.

13. Presidential Communications Operations Office (PCOO). OFW deployment ban to Kuwait stays [Online]. 2018 February 22 [cited 2018 May 15]. Available from https://pcoo.gov.ph/news_releases/ofwdeployment-ban-kuwait-stays/.

14. Battistella G, Asis M. Protecting Filipino transnational domestic workers: Government regulations and their outcomes, Philippine Institute for Development Studies, Discussion Paper Series No. 201112. Makati City, Philippines. 2011.

15. CMA. CMA Working Paper on Overseas Migration (Unpublished). 2011. 
16. Senate of the Philippines 17th Congress, Press Release,September 9, 2013. 3732 OFWs in jails in 53 countries [Online]. 2013 September 9 [cited 2018 May 12]. Available from http://www.senate.gov.ph/press_ release/2013/0909_recto1.asp.

17. Administrative Order No. 168. Manual operations, policies, and guidelines for the Philippine Overseas Labor Office. 2013.

18. Republic Act 10801. An Act governing the operations and administration of the Overseas Workers Welfare Administration. 16th Congress, 3rd Session. 2016.

19. Republic Act 9710. Magna Carta for Women. 2009.

20. Embassy of the Philippine: Athens, Greece. Philippine Overseas Labor Office (POLO) [Online]. n.d [cited 2018 May 15]. Available from http://www.athenspe.dfa.gov.ph/philippine-overseas-labor-officepolo.

21. OWAA [Homepage of OWWA's Workers Welfare Assistance Program] [Online]. n.d [cited 2018 May 12]. Available from http:// owwa.gov.ph/programs-services/welfare.
22. DILG. Memorandum Circular No. 2018-62. Local Government Units roles and responsibilities in the implementation of the inter-agency medical repatriation assistance program for overseas Filipinos. 2018.

23. WHO \& DOH. WHO-AIMS Report on Mental Health System in the Philippines, Manila, Philippines. 2006.

24. Department of Health Administrative Order No. 2007-0009. Operational Framework for the Sustainable Establishment of a Mental Health Program, 2007.

25. Republic Act 11036. An act establishing a national mental health policy for the purpose of enhancing the delivery of integrated mental health services, promoting and protecting the rights of persons utilizing psychiatric, neurologic and psychosocial health services, appropriating funds therefor and for other purposes. 2018.

26. Psychological Association of the Philippines. Press Briefing: Philippine Mental Health Act [Online]. 2018 June 22 [cited 2018 July 28]. Available from https://www.pap.org.ph/news/201807/press-briefingphilippine-mental-health-act-ra-11036.
Have you read the current trends in Medical and Health Research in the Philippines?

\section{Acta Medica Philippina The National Health Science Journal}

